GRASAS Y ACEITES 70 (1)

January-March 2019, e291

ISSN-L: 0017-3495

https://doi.org/10.3989/gya.0571181

\title{
First seasonal investigation of the fatty acid composition in three organs of the Tunisian bivalve Mactra stultorum
}

\author{
I. Chetoui ${ }^{\bowtie}$, I. Rabeh, S. Bejaoui, K. Telahigue, F. Ghribi and M. El Cafsi \\ Faculty of Sciences of Tunis, Biology Department, Research Unit of Physiology and Aquatic Environment, \\ University of Tunis El Manar, 2092 Tunis, Tunisia. \\ ${ }^{\square}$ Corresponding author: chetouiimene@gmail.com
}

Submitted: 07 May 2018; Accepted: 03 September 2018

SUMMARY: This study reveals information for the first time about the total lipid (TL) content and fatty acid composition (FA) of Mactra stultorum ( . corallina). Three edible organs (foot, mantle and adductor muscle) were the subjects of this research in order to determine the most favorable periods for their consumption in relation to seasonal variability. The results showed lower lipid content in the adductor muscles in summer (12.73 \pm $2.55 \mathrm{mg} / \mathrm{g}$ dry matter); while a higher content was observed in winter $(28.97 \pm 3.50 \mathrm{mg} / \mathrm{g}$ dry matter). However, similar lipid contents were observed in the mantle and foot tissues among the seasons. The fatty acid composition of Mactra stultorum adductor muscles, mantle and foot was dominated by saturated fatty acids (SFA) and polyunsaturated fatty acids (PUFA). Palmitic acid (16:0) was the major saturated fatty acid (SFA) and reached higher levels during summer in the foot $(26 \%)$, mantle $(21 \%)$ and adductor muscles $(25 \%)$. Among PUFA, eicosapentaenoic acid (EPA, 20:5n-3) and docosahexaenoic acid (DHA, 22:6n-3) showed significant variation among seasons with high levels recorded during winter and spring. Monounsaturated fatty acids (MUFA) did not show any remarkable variation among seasons for the three studied tissues. Seasonal changes in fatty acids were observed for all samples, reaching a maximum level in winter or spring.

KEYWORDS: Fatty acid composition; Mactra corallina; Season; Total lipid

RESUMEN: Primera investigación sobre el perfil de ácidos grasos de Mactra corallina (Bivalvia, Mactridae) de la costa norte de Túnez. Este estudio proporcionó información por primera vez sobre el contenido total de lípidos (TL) y la composición de ácidos grasos (AG) Mactra stultorum (M. corallina). Tres órganos comestibles (pie, manto y músculo aductor) son el objeto de esta investigación para determinar los períodos más favorables para su consumo en relación con la variabilidad estacional. Los resultados mostraron niveles más bajos de lípidos en los músculos aductores en verano $(12,73 \pm 2,55 \mathrm{mg} / \mathrm{g}$ de materia seca), mientras que en invierno se observó un mayor contenido $(28,97 \pm 3,50 \mathrm{mg} / \mathrm{g}$ de materia seca). Sin embargo, se observaron contenidos similares de lípidos en los tejidos del manto y el pie entre las estaciones. La composición grasa de los músculos aductores Mactra stultorum, el manto y el pie estuvo dominada por ácidos grasos saturados (AGS) y ácidos grasos poliinsaturados (AGPI). El ácido palmítico (16:0) fue el principal ácido graso saturado (AGS) alcanzando niveles más altos durante el verano en pie (26\%), el manto (21\%) y los músculos aductores (25\%). Entre los ácidos grasos poliinsaturados (AGPI), el ácido eicosapentaenoico (EPA, 20:5n-3) y ácido docosahexaenoico (DHA, 22:6n-3), han mostrado una variación significativa entre las estaciones, con niveles altos registrados durante el invierno y la primavera. Mientras que, los ácidos grasos monoinsaturados (AGMI) no mostraron ninguna variación notable entre las estaciones para los tres tejidos estudiados. Se pueden observar cambios estacionales de los ácidos grasos para todas las muestras que alcanzan un nivel máximo en invierno o primavera.

PALABRAS CLAVE: Composición de ácidos grasos; Estación; Lípido total; Mactra stultorum

ORCID ID: Chetoui I https://orcid.org/0000-0002-2259-5397, Rabeh I https://orcid.org/0000-0002-0307-473X, Bejaoui S https://orcid.org/0000-0002-7946-2763, Telahigue K https://orcid.org/0000-0001-8841-9911, Ghribi F https://orcid. org/0000-0001-9350-7510, El Cafsi M https://orcid.org/0000-0003-0479-8710

Citation/Cómo citar este artículo: Chetoui I, Rabeh I, Bejaoui S, Telahigue K, Ghribi F, El Cafsi M. 2019. First seasonal investigation of the fatty acid composition in three organs of the Tunisian bivalve Mactra stultorum. Grasas Aceites 70 (1), e291. https://doi.org/10.3989/gya.0571181

Copyright: (02019 CSIC. This is an open-access article distributed under the terms of the Creative Commons Attribution 4.0 International (CC BY 4.0) License.

\section{ABBREVIATION}

Dry matter (DM), Total lipid (TL), Fatty acid (FA), Docosahexaenoic acid (DHA), Eicosapentaenoic acid (EPA), Saturated fatty acids (SFA), Monounsaturated fatty acids (MUFA), Polyunsaturated fatty acids (PUFA), Arachidonic acid (ARA), Linoleic acid (LA) 


\section{INTRODUCTION}

The rayed trough-shell Mactra stultorum $(=$ M. corallina $)$ (Linnaeus 1758) is a commercially important benthic clam that inhabits sandy bottoms at depths between 5 and $30 \mathrm{~m}$. It is a medium-sized marine bivalve with a very thin and delicate shell with concentric growth lines (Guarniero et al., 2010). $M$. stultorum is distributed along the coastlins of the Black Sea, Mediterranean Sea and the Eastern Atlantic Ocean from Norway to Senegal (FAO, 1987). This species occupies an important trophic level in the food chain, and is a source of food for crustaceans, gastropods and macrophage fish (Mnari, 2000). M. coralline was reported in Northern (Gulf of Tunisia) and Southern (gulf of Gabes) Tunisian Coasts by Enzenros (2001) and Seurat (1934). This clam is commercially exploited and consumed in the Atlantic Sea (e.g Manche coasts) (Direction Départementale des affaires maritimes de la Manche, 2013), while it is virtually unexploited and not yet commercialized in the Mediterranean Sea.

Sea organisms, in particular, bivalves are considered a good source of omega 3 fatty acids such as eicosapentanoic (EPA, 20:5n-3) and docosahexanoic (DHA, 22:6n-3) acids that are crucial for human nutrition and health (Shanmugam et al., 2007). It has been well demonstrated that these fatty acids are beneficial for human health and for the prevention of many diseases (coronary artery disease, inflammatory and autoimmune diseases etc.) (Harris and Schacky, 2004; Calder and Grimble, 2002; Gil, 2002). Shellfish are also rich in protein, amino acids, vitamins (e.g. B12), essential elements (Calcium, Magnesium, Zinc...) and are frequently considered a healthy food for human consumption (Ghribi et al., 2018; Dong, 2001).

Lipids are considered essential compounds for the formation of cells, tissue membrane and egg production and are also used in chronic stress (Napolitano et al., 1992; Nevejan et al., 2003). Lipids are a major source of metabolic energy and support animal growth when the food supply from the environnement is limited (Holland, 1978). According to Teshima et al., (1988), the distribution of lipids in different organs and tissues depends on their metabolism (digestion, absorption, modification, transport and storage). Lipids and fatty acids in the soft tissue of marine bivalves undergo seasonal fluctuations, which are controlled by exogenous factors (food availability, temperature, salinity etc.) and by endogenous factors (physiological status) (Prato et al., 2010).

Previous studies on $M$. stultorum investigated the Mediterranean Sea (1) and populations (2). They included research on genetics and ecology (Chetoui et al, 2012; et al., 2016) and biology (Chetoui et al., unpublished data).

The lipid content of this species was described by Hanus et al., (2009) in the plasmogen fraction of Mactra corallina but no data are available on its fatty acid composition and nutritional value during an annual cycle. To the best of our knowledge, the fatty acid composition and nutritional quality indices in different edible organs (mantle, foot and adductor muscle) of Mactra stultorum are examined for the first time.

The aim of this work was to study the seasonal variations in the fatty acid profiles of the M. stultorum population from the Tunisian Coasts and to examine the potential influence of environmental parameters and reproductive cycle on its nutritional quality. The results provided by the current study will be useful for indicating periods of the year that are more suitable for the consumption and marketing of $M$. coralline as a new marine resource in Tunisia.

\section{MATERIALS AND METHODS}

\subsection{Animals}

Specimens of Mactra stultorum $(>3.5 \mathrm{~cm})$ were collected over a period of 12 months (from June 2008 to May 2009) from the sandy beach of Kalaat El Andalous (Gulf of Tunisia). The sampling site was located at $37^{\circ} \mathrm{N} 10^{\circ} 67^{\prime} \mathrm{E}$ (Figure 1). After sampling, Mactra stultorum ( $\mathrm{n}=6$ each month) were brought to the laboratory in cool boxes. The shells were opened to collect the fresh tissues: adductor muscle (AM), mantle (MT) and foot (FT) and stored at $-20^{\circ} \mathrm{C}$ until analyses.

At the sampling site, temperature $\left({ }^{\circ} \mathrm{C}\right)$ was measured every month with a thermometer. In the laboratory, chlorophyll $a$ was extracted using Whatman GF/F filters with $90 \%$ methanol and its concentration was determined according to the method of (Aminot and Chaussepied, 1983).

\subsection{Lipid extraction}

Lipids were extracted according to Folch et al., (1957) method with a chloroform: methanol $(2: 1, \mathrm{v} / \mathrm{v})$ solution containing $0.01 \%$ butylatedhydroxyl toluene (BHT) as antioxidant. The total lipid content was determined by double weighing and expressed as $\mathrm{mg} / \mathrm{g} \mathrm{DM}$.

Fatty acid composition. The Lipid fraction was transesterified to methyl esters according to Cecchi et al., (1985). Methyl nonadecanoic acid C19:0 (Sigma), which was absent from our samples, was added as internal standard. Methyl esters were analyzed by gas chromatography using a chromatogram "Agilent Technologies" HP 6890 model equipped with a capillary column INNO-WAX $(30 \mathrm{~m} \times 0,25 \mu \mathrm{m})$ and supplied by a carrier gas of nitrogen. The temperature program during the injection was started with a temperature of $50^{\circ} \mathrm{C}$. Thereafter, the $\mathrm{T}^{\circ} \mathrm{C}$ was raised to $180{ }^{\circ} \mathrm{C}\left(40{ }^{\circ} \mathrm{C} / \mathrm{min}\right)$, then to $220^{\circ} \mathrm{C}\left(1.33^{\circ} \mathrm{C} / \mathrm{min}\right)$. Finally, it was held at $220^{\circ} \mathrm{C}$ for $5 \mathrm{~min}$. 


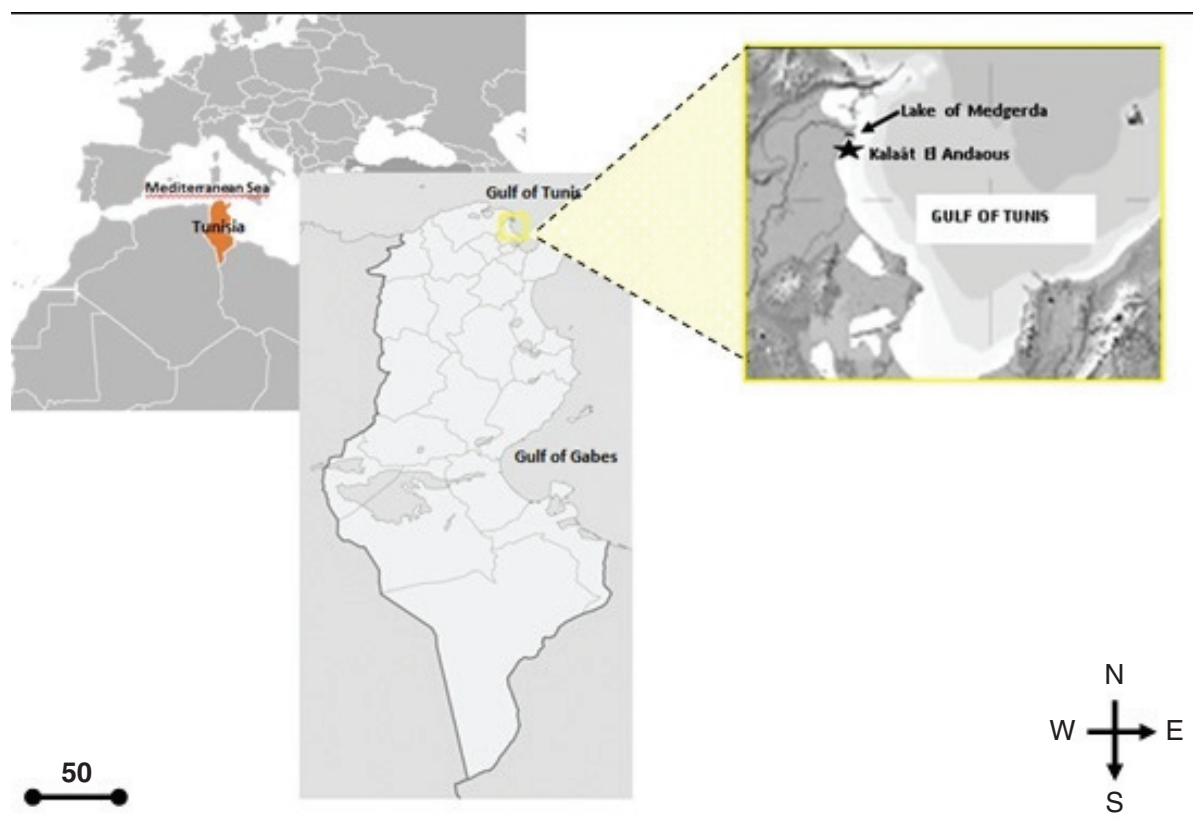

FIgURE 1. Map of the Tunisian sample location

The oven was programmed to rise from 50 to $180^{\circ} \mathrm{C}$ at a rate of $4{ }^{\circ} \mathrm{C} / \mathrm{min}$, from 180 to $220^{\circ} \mathrm{C}$ at $1.33^{\circ} \mathrm{C} / \mathrm{min}$ and to stabilize at $220^{\circ} \mathrm{C}$ for $7 \mathrm{~min}$.

Identification of FAMEs was based on the comparison of their retention times with those of a mixture of methyl esters PUFA-3 (by SUPELCO) and Marine oil (Mehaden oil by SUPELCO).

Fatty acid peaks were integrated and analyzed using HP chemstation software.

\subsection{Data analysis}

Data analyses were made using the software Statistica version 5.0. Lipids contents were expressed as $\mathrm{mg} / \mathrm{g}$ Dry Matter. Fatty acids were expressed in percentages. Data was presented as the seasonal average \pm the standard deviation (SD). The averages were compared by the analysis of variance (ANOVA). The Duncan's test and Pearson correlation were applied. The differences were considered significant when $P<$ 0.05 . The mean variance in the data set was detected using the principal component analysis (PCA).

\section{RESULTS}

\subsection{Total lipid content in the foot, mantle and adductor muscle of $M$. stultorum}

Figure 2 shows the seasonal fluctuations of temperature and chlorophyll $a$ content. Temperature values varied between $10.3{ }^{\circ} \mathrm{C}$ (winter) and $26.3^{\circ} \mathrm{C}$ (summer). The quantity of chlorophyll $a$ observed in our study ranged from 2.84 (autumn) to $4.44 \mathrm{mg} / \mathrm{l}$ (summer).

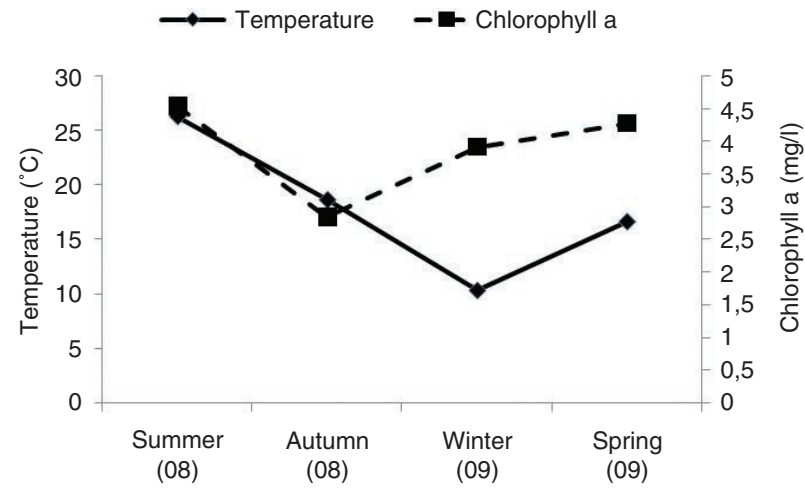

FIGURE 2. Seasonal variation in the surface seawater temperature and chlorophyll $a$ at sampled location.

Seasonal variations total lipid content (TL) in the three organs of $M$. stultorum are represented in Figure 3. The mantle has the highest amount of TL during all the sampled seasons ( $>30 \mathrm{mg} / \mathrm{g} \mathrm{DM})$. In the foots, it ranged between 15 and $20 \mathrm{mg} / \mathrm{g} \mathrm{DM}$. However, the TL content in the adductor muscle varied significantly among seasons, when the loweat contents were registered in summer $(12.73 \pm 2.55$ $\mathrm{mg} / \mathrm{g} \mathrm{DM}$ ) and the highest value was observed during the winter $(28.97 \pm 3.50 \mathrm{mg} / \mathrm{g} \mathrm{DM})$.

\subsection{Fatty acid compositions in the foot, mantle and adductor muscle of $M$. stultorum}

The seasonal variation in the fatty acid composition of M. stultorum is summarized in Table 1. In this study, thirty fatty acids (FA) were identified and three 


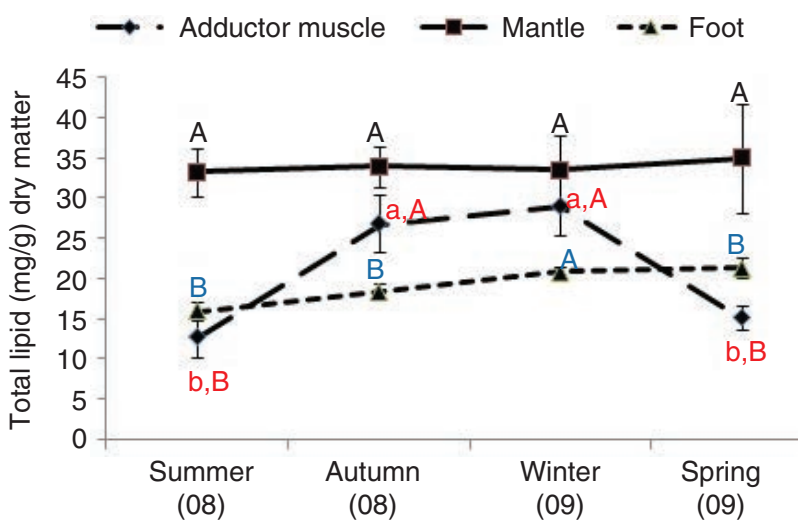

FiguRE 3. Seasonal variation in total lipid content in foot (FT), mantle (MT) and adductor muscle (AM) of Mactra stultorum. Values expressed as mg/g Dry Matter ( $\mathrm{n}=6$ each month). Different minuscule letter indicate significant differences

between seasons in each organ (Duncan's tests, $P<0.05$ ). Different capital letter indicate significant differences among organs (Duncan's tests, $P<0.05$ ).

Absence of minuscule and capital letters means no significant effect $(P<0.05)$.

families were determined. Palmitic acid (C16:0) was the major saturated fatty acid (SFA), ranged between a minimum $17 \%$ (in the mantle during winter) and a maximum $26.75 \%$ (in the foot during summer). No significant differences were found for $\mathrm{C} 16: 0$ among organs. However, three FA such as 16:1; 18:1 and C20:1 were considred remarkable MUFA for MT, FT and AM in all the seasons. Nonetheless, eicosapentanoic acid (EPA, 20:5n-3) and docosahexanoic acid (DHA, 22:6n-3) predominated the polyunsaturated fatty acids (PUFA). For all organs, the values of EPA and DHA ranged from 4 to $10 \%$ and from $7 \%$ to $20 \%$, respectively.

Non-methylene-interrupted dienoic acids (NMID; $22: 2 \mathrm{i}+22: 2 \mathrm{j}$ ) are considered fatty acid characteristics of bivalve, and were also determined in $M$. corallina. In addition, NMID were low in the foot (from $1 \%$ to $2.60 \%$ ) compared to the mantle $(>2.60 \%)$ and adductor muscle $(>2.30 \%)$.

A statistical analysis between the fatty acid composition of M. stultorum and environmental parameters (temperature and chlorophyll $a$ ) was tested by ANOVA. The results showed a negative and significant correlation between PUFA and n-3 PUFA and adductor muscles and chlorophyll $a$.

The variation in fatty acid families among the organs such as SFA, MUFA and PUFA are represented in Figure 4. For all seasons, the M. stultorum foot has the highest values of SFA (comprised between $37 \%$ and $49 \%$ ). While, in the mantle and adductor muscles, SFA were below 40\%. Only in winter, did we observe a significant variation $(\mathrm{p}<0.05)$ among organs (Figure $\mathrm{a}_{4}$ ). MUFA percentages in the adductor muscle were constant and comprised between 19 and 20\%. Nevertheless, in the mantle and foot, they were higher during the

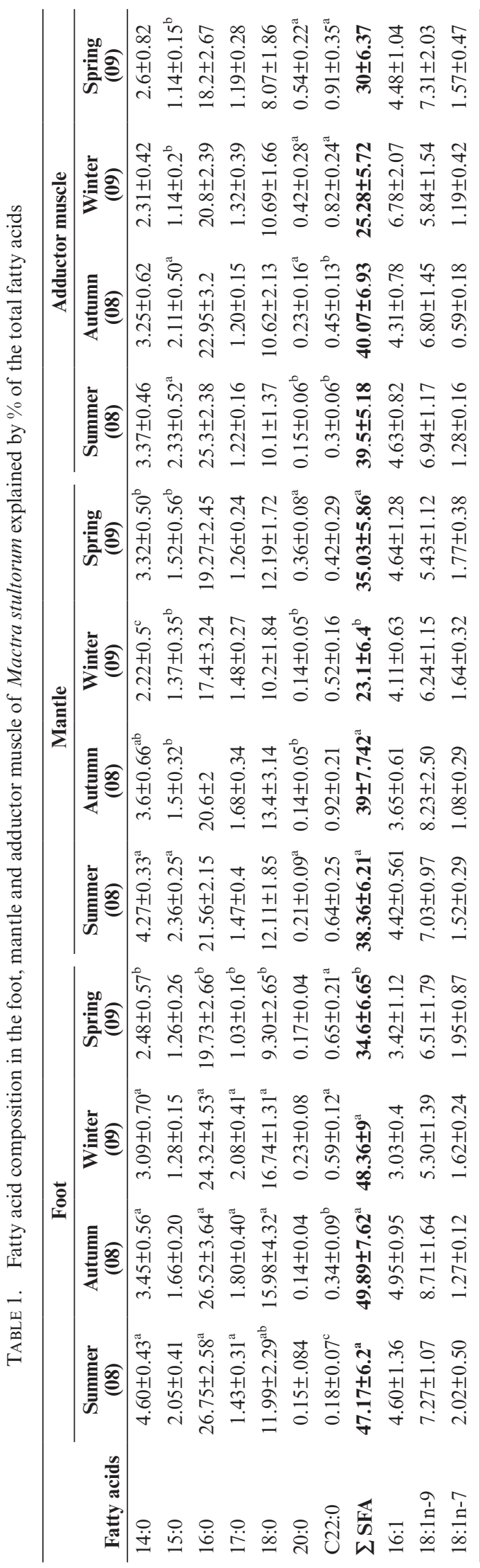




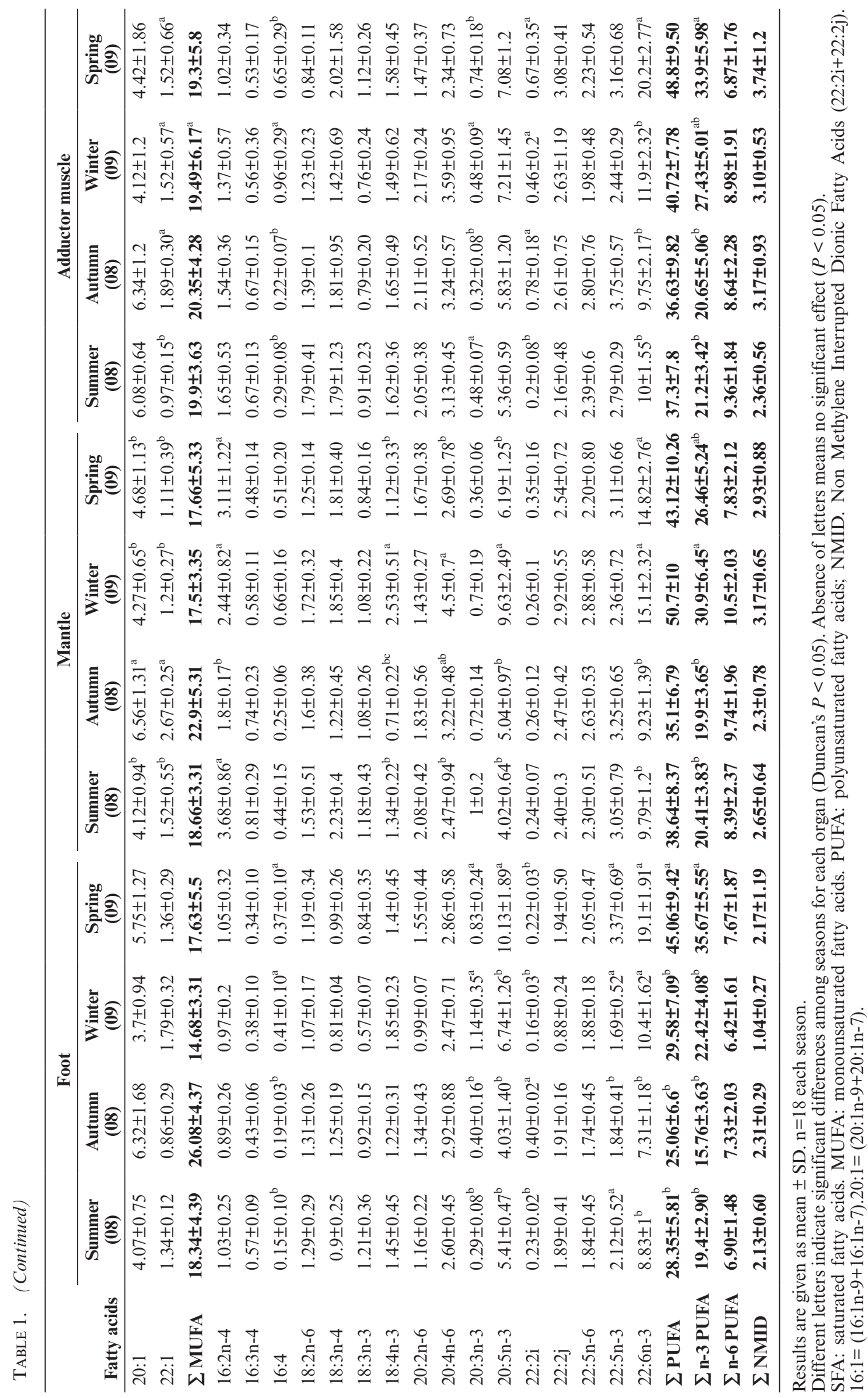


$\left(a_{4}\right)$

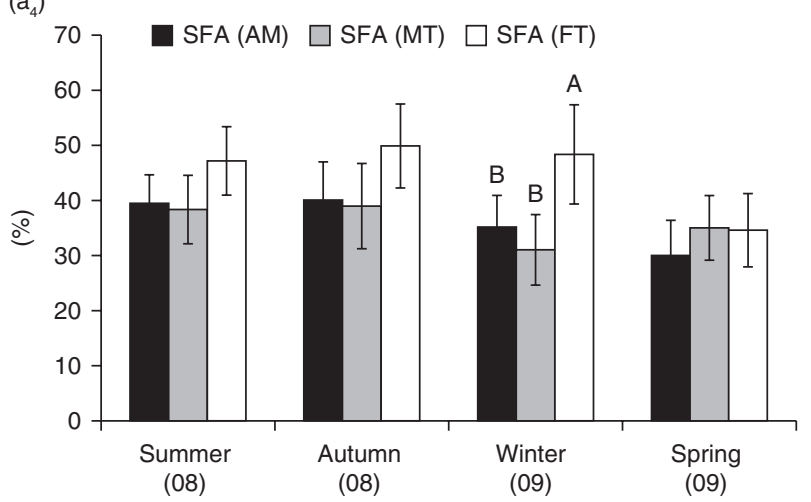

$\left(b_{4}\right)$

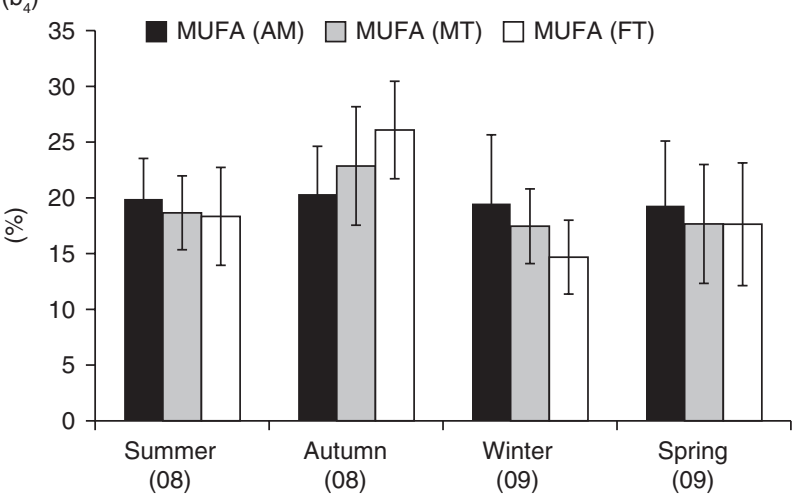

$\left(c_{4}\right)$

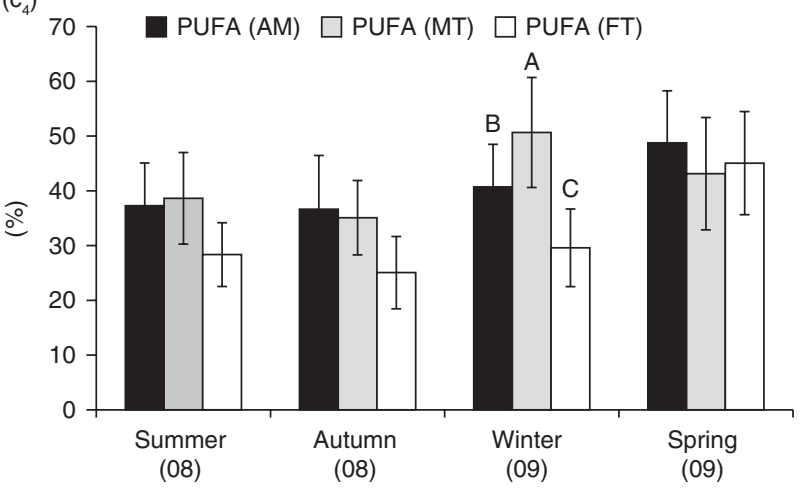

Figure 4. The evolution of fatty acid families in the foot (FT), mantle (MT) and adductor muscle (AM) of Mactra stultorum. Values are expressed as means $\pm \mathrm{SD}(\mathrm{n}=6$ each season).

$\mathrm{a}_{4}$ : Saturated fatty acids (SFA); $\mathrm{b}_{4}$ : Monounsaturated fatty acids (MUFA); $\mathrm{c}_{4}$ : Polyunsaturated fatty acids (PUFA). Different capital letter indicate significant differences among organs (Duncan's tests, $P<0.05$ ).

Absence of minuscule and capital letters means no significant effect $(P<0.05)$.

summer (22\% and 26\% respectively) and lower in the winter (17\% and $14 \%$ respectively) (Figure $\left.b_{4}\right)$. PUFA values for $M$. stultorum were similar in summer and autumn (fig. $\mathrm{c}_{4}$ ). They increased to reach a maximum in spring in the order of $48.76 \pm 9.50 \%$; $43.12 \pm 10.26 \%$ and $45.05 \pm 9.42 \%$ for AM, MT and FT respectively $(\mathrm{p}<0.05)$.

Some ratios or lipid quality index were calculated for M. stultorum which reflect the nutritional

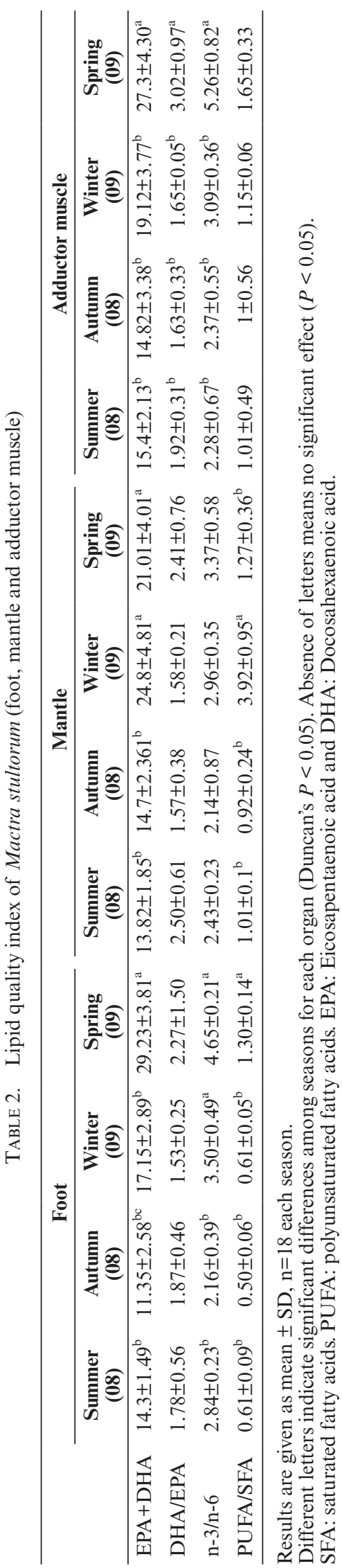


quality of the flesh (Table 2). Two first ratios were calculated in our study such as EPA+ DHA and EPA/DHA ratios, which were higher during spring with values estimated at 25 and $2 \%$, respectively in all the organs of $M$. corallina. The PUFA/SFA ratio varied from 0.5 to 1 for all the organs during the 4 seasons; except for the mantle in winter, which increased to 3 . Nevertheless, the (n-3) / (n-6) ratio was comprised between 2 to 5 in the three organs.

\subsection{Principal component analysis (PCA)}

The principal component analysis was performed with respect to the effect of seasonality on the fatty acid composition in the three organs of Mactra. The loading plot is represented in Figure 5A. Factor 1 displayed $16.12 \%$ variance, which was defined by SFA (C16:0; C17:0 and C18:0), whereas Factor 2 demonstrated a variance of $13.86 \%$ and characterized by C16:1; C20:1, C20:4n-6 and C22:5n-3 variables. The percentages of SFA in the foot, mantle
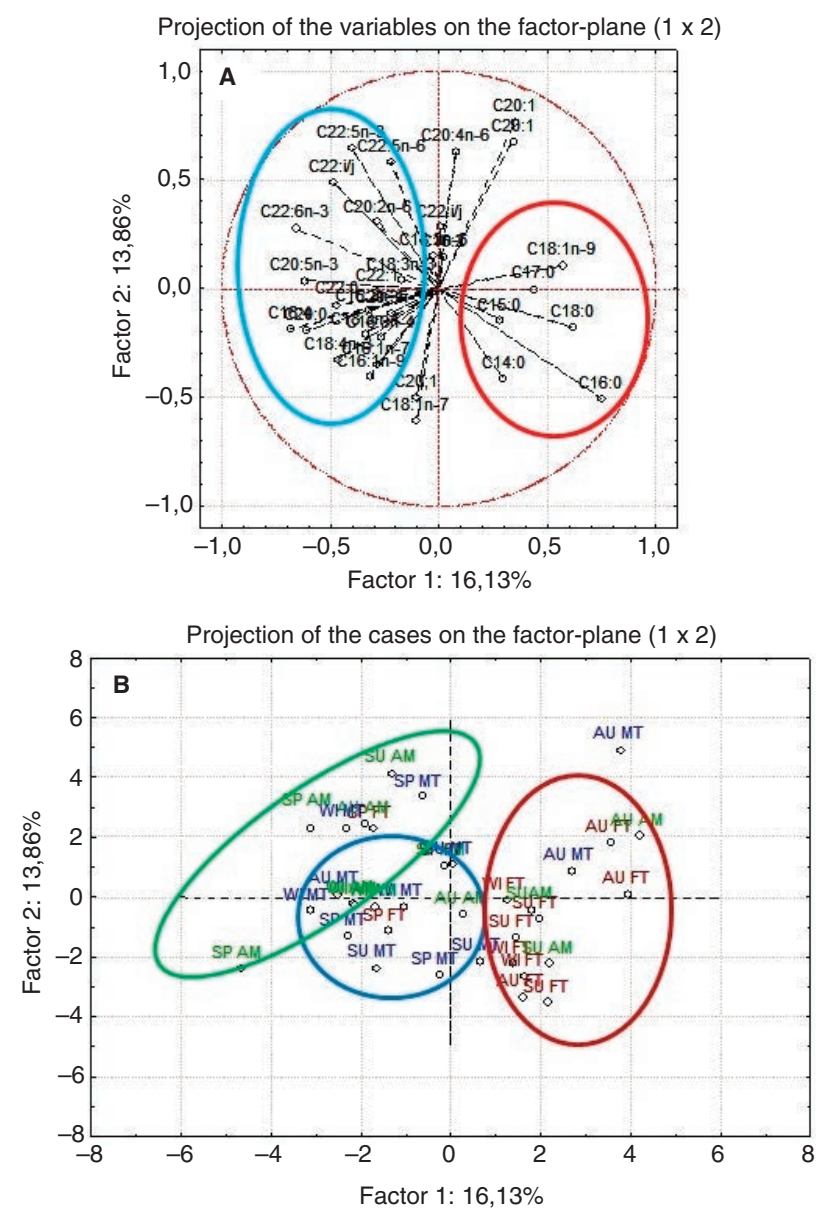

FIGURE 5. Results of PCA principal analysis component represented by two factors $\mathrm{F} 1$ and $\mathrm{F} 2$ and produced by seasonal variation in fatty acid composition in the foot (FT), mantle (MT) and adductor muscle (AM) of Mactra stultorum. A: Projection of the variables on the factor-plane $(1 \times 2), \mathrm{B}$ : Projection of the cases on the factor-plane $(1 \times 2)$. and adductor muscle showed a positive correlation with those of MUFA, which varied similarly during the seasons (except in spring). In contrast, the n-3 PUFA percentages were projected on the negative side of Factor 1 and Factor 2. Figure 5B showed that there is an overlap between two groups: mantle and adductor muscles. This observation confirms the similarity of fatty acid compositions during the 4 seasons. However, the fatty acid composition in the foot formed a separate group.

\section{DISCUSSION}

The present study showed that the total lipid content observed in M. stultorum was similar to those found in M. verneriformis (Qiaozhen and Qi, 2013) $\mathrm{f}$ and in $M$. chinensis (Li et al., 2011) from the Eastern Coast of China.

For aquatic organisms such as bivalves, lipids are considered an important dietary constituent. In stressful environmental conditions and after the depletion of glycogen, the total lipid contet is used as an energy source during the reproduction process (Couturier and Newkirk, 1991). In the current work, a significant decrease in TL, especially in the adductor muscles of $M$. stultorum was observed. We suppose that this reduction could be related to the reproductive cycle of this species.

It is likely that this animal mobilizes the lipids from the muscle to be stored in the gonads for use during the maturation stage. This was confirmed by the reduction in the TL content in $M$. stultortum during the spawning phase that occured from summer to autumn (Chetoui, 2016). In contrast, no significant differences were observed in the TL content of the $M$. stultorum foot and mantle. In general, the digestive gland, gonads and adductor muscles of bivalve species were considered as organs of energy storage during the reproductive cycle (Darriba et al., 2005)

Fatty acids are vital components needed by the body for different metabolic and structural functioning. In our study, the fatty acid compositions in $M$. stultorum are in agreement with several investigations carried out on M. chinensis (Teshima et al., 1988) and Ruditapes decussates (Pazos et al., 2003). In addition, our results on the dominance of SFA and PUFA in M. stultorum were in agreement with the findings of Teshima et al. (1988) in M. chinensis and Besnard (1988) in $P$. maximus. Other investigations have demonstrated that n-3 PUFA proportion was accumulated at high levels in the muscle of Megangulus zyonoensis and Megangulus zyonoensis (Kawashima and Ohnishi, 2003). However, SFA was shown to be the more dominant in Glycymeris glycymeris tissues than PUFA and MUFA (Galap et al., 1999).

The seasonal variation in SFA (16:0 and 18:0) in M. stultorum was marked by a significant reduction during spring. This decrease was followed by a slight 
increase in MUFA content in all the studied organs. It could be due to the action of delta-9 desaturase that probably transformed SFA to MUFA (e.g. palmitoleic acid (16:1n-7) and Oleic acid (18:1n-9)) (Sprecher, 2000).

Indeed, many studies have showen that the PUFA level in bivalves reflect their good nutritional quality (Fernández et al., 1996).

Other investigtions have reported that this important proportion of PUFA probably resulted from their transfer from other reserve tissues such as the gonads and digestive glands to the mantel (Le Pennec et al., 2001; Darriba et al., 2005).

The seasonal variation in ARA for M. stultorum did not present any differences in all seasons among the organs except in winter for the Mantle. This exception was characterized with an increase in the ARA level associated with a decrease in LA level. This was probably due to the stress effects on the animals following a drop in water temperature during this period $\left(10.33 \pm 3^{\circ} \mathrm{C}\right)$ (Pernet et al., 2007). In fact, LA is considered the main precursor of ARA, which can confirm their elevation.

n-3 PUFA, including EPA (C20:5n-3) and DHA (C22:6n-3), are considered essential fatty acids and dietary fats which are beneficial to human health (Dong 2001). During the spring, the foot of M. stultorum appeared as the richest organ in EPA and DHA, coinciding with a máximum level of chlorophyll $a$ $(4.28 \mathrm{mg} / \mathrm{l})$. AM and MT did not show a significant variation during the studied period. The results of essentials fatty acids in our study from the Mediterranean Coast reminded us of those found in M. chinensis from the Pacific Coast (Teshima et al., 1988). Likewise, other authors have shown that an increase in n-3 PUFA; especially EPA and DHA may reduce cardiovascular risk in consumers of marine products by up to $50 \%$ (Angerer and Sclaky, 2000). In addition, these fatty acids were of great interest for cardiovascular and some cancer treatments (Fenton et al., 2000).

The edible portion of M. stultorum was found to be rich in these essentials fatty acids (EPA and DHA). Their important nutritional quality was in accordance with other bivalves such as $M$. chinensis, $M$. veneriformis and $M$. murchisoni which are considered important commercial seafood (Ryou, 1997; Wu et al., 2002; Nottinghram and White, 2015).

For the Non-methylene-interrupted dienoic (NMID; C22:2i+C22:2j), the adductor muscle and mantle showed important percentages during all periods $(>2 \%)$. Fatty acid Non-methyleneinterrupted dienoic (NMID) are polyunsaturated fatty acids, of 22 carbon atoms (C22:2i and C22: $2 \mathrm{j}$ ), synthesized by shellfish, in particular bivalves (Zhukova, 1991). Their structures were established as $\mathrm{C} 20: 2 \Delta 5-11, \mathrm{C} 20: 2 \Delta 5-13, \mathrm{C} 22: 2 \Delta 7-13$ and $\mathrm{C} 22: 2 \Delta 7-15$. It was suggested that these fatty acids in animals are derived almost exclusively from food sources and are biochemically inert (Paradis and
Ackman, 1975). For M. corallina, levels of C22:2i were lower than those of $\mathrm{C} 22: 2 \mathrm{j}$ and their sums varied between $1 \%$ and $3.74 \%$. These levels were reversed in $M$. chinensis, which showed higher values which can reach 5\% (Hiroaki, 2007). Our results were comparable to those reported in oysters Crassostrea gigas (Dridi et al., 2007); in mussels Mytilus galloprovincialis (Garrido and Medina, 2002) and in pectenidae (Telahigue et al., 2010).

Concerning the lipid quality index, Kraffe et al., (2008) showed that EPA+DHA in Manila clams were closer to our results $(14.9 \%)$. However, EPA+DHA reflected more functional and structural modifications of mitochondrial membranes of this bivalve than others such as scallops, oysters, and mussels (Kraffe et al., 2008). So, our values for the PUFA/ SFA ratio were higher than those suggested by the Department of Health and Social Security (1994); which were estimated at 0.45 . In addition, the (n-3)/ (n-6) ratio calculated in our study was close to the one indicated for M. chinensis (Teshima et al., 1988). Compared to other bivalve from the Mediterranean Sea, the n-3/n-6 ratio was higher than those reported for oyster Crassostrea gigas (2.8) and lower than those recorded for the Pectinidae family (Dridi et al., 2007; Telahigue et al., 2010). According to the UK Department of Health, an ideal proportion of $n-6 / n-3$ is recommended at 4.0 (HMSO, 2001). So, a ratio greater than 4.0 was considered harmful to human wellbeing (Andrade et al., 1995). In the present study, $n-3 / n-6$ ratio is greater than 2 and the $\mathrm{n}-6 / \mathrm{n}-3$ ratio is lower than 1 . Therefore, $M$. stultorum can be considered as part of a healthy diet.

\section{CONCLUSIONS}

In the light of these results, Mactra stultorum was shown to be a good source for some important fatty acids such as high levels of n-3 PUFA, EPA and DHA. The seasonal variation in fatty acid composition showed a difference among the three studied organs of Mactra stultorum (foot, mantle and adductor muscle). Moreover, spring was considered a remarkable season which was characterized by higher fatty acid levels due to the food availability in the natural environment. According to our results Mactra stultorum may be considered a good resource for manufacturing animal foodstuff and breeding.

\section{ACKNOWLEDGMENTS}

This study was supported by the Tunis University of Sciences and the research Unit of Physiology and Aquatic Environment. We were grateful to Mr. Hassen Mejri (University of Tunisia) for his technical assistance with the gas chromatography analysis.

Note: No conflict of interest exists. 


\section{REFERENCES}

Aminot A, Chaussepied C. 1983. Manuel des analyses chimiques en milieu marin. Centre National d'Exploitation des Océans, Brest, 395. pp.

Andrade AD, Rubira AF, Matsushita M, Souza NE. 1995. Omega-3 fatty acids in freshwater from South Brazil. $J$. Am. Oil. Chem. Soc. 72, 1207-1210. https://doi.org/10.1007/ BF02540990

Angerer P, Sclaky V. 2000. n-3 polyunsaturated fatty acids and the cardiovascular system. Curr. Opin. Lipido 11, 57-63. https://doi.org/10.1097/00075197-200011000-00005

Beninger PG, Lucas A. 1984. Seasonal variations in condition, reproductive activity and gross chemical composition of 2 species of adults clam reared in a common habitat: Tapes decussatus L. (Jeffreys) and Tapes philippinarum (Adams, Reeve). J. Exp. Mar. Biol. Ecol. 79, 19-37. https://doi.org/ 10.1016/0022-0981(84)90028-5

Besnard JY. 1988. Etude des constituents lipidiques dans la gonade femelle et les larves de Pecten maximus L. Ph.D., thesis, Univ, Caen, 154. pp.

Calder PC, Grimble R.F. 2002. Polyunsaturated fatty acids, inflammation and immunity. Eur. J. Clin. Nutr. 56, 14-19. https://doi.org/10.1007/s11745-001-0812-7

Cecchi G, Basini S, Castano C. 1985. Méthanolyse rapide des huiles en solvant. Rev. Franç. Corps Gras 4.

Chetoui I. 2016. Variabilité morphologique, biochimique et diversité génétique des populations de Mactra stultorum (Bivalve, Mactridae) des côtes tunisiennes: implication dans la valorisation et la conservation de l'espèce. Ph.D. thesis, F.S.T., Tunis, 279.pp.

Chetoui I, El Cafsi M, Boussaid M. 2012. Allozymic and morphological variation in three populations of surf clam Mactra corallina (Bivalvia: Mactridae) from Tunisian sandy beaches. Cah. Biol. Ma. 53, 409-417. https://doi. org/10.13140/RG.2.1.3902.4081

Chetoui I, Denis F, Boussaid M, Telahigue K, El Cafsi M. 2016. Genetic diversity and phylogenetic analysis of two Tunisian bivalves (Mactridae) Mactra corallina (Linnaeus, 1758 ) and Eastonia rugosa (Helbling, 1799) based on COI gene sequences. C. R. Biol. 339, 115-122. https://doi.org/ 10.1016/j.crvi.2016.02.001

Cotronea A, Ziino M, Alfa M, Salvo F, Dogo G. 1980. Scarti di pesca nellalimentazione di Penaeus cherturus. in Ekin I, Başhan M. 2010. (ed.) Fatty Acid Composition of Selected Tissues of Unio elongatulus (Bourguignat, 1860) (Mollusca: Bivalvia) Collected from Tigris River, Turkey. Turkish $J$. Fisheries Aquatic Sci. 10, 445-451.

Couturier CY, Newkirk G.F. 1991. Biochemical and gametogenic cycles in scallops, Placopecten magellanicus (Gmelin, 1791), held in suspension culture. in Shumway S.E, Sandifer P.A. (Ed.) An International Compendium of Scallop Biology and Culture. Baton Rouge, LA. J. World. Aquacult. Soc. 107-117.

Darriba S, Juan FS, Guerra A. 2005. Energy storage and utilization in relation to the reproductive cycle in the razor clam Ensis arcuatus (Jeffreys, 1865), ICES. J. Mar. Sci. 62, 886-896. https://doi.org/10.1016/j.icesjms.2005.02.010

Department of Health and Social Security. 1994. Nutritional aspects of Cardiovascular Disease Report on health and social subjects, 46, London, HMSO.

Direction Départementale des affaires maritimes de la manche. 2013. Tailles de Capture, période de pêche, engins de autorisés et quantités maximales de pêche par jour et par pécheur pour les espèces de coquillage, poissons, crustacés et céphalopodes, Manche, pp. 2.

Dong FM. 2001. The nutritional value of shellfish, Washington Sea Grant Program, University of Washington.

Dridi S, Romdhane MS, El Cafsi M. 2007. Seasonal variation in weight and biochemical composition of the Pacific oyster, Crassostrea gigas in relation to the gametogenic cycle and environmental conditions of the Bizerte lagoon, Tunisia. Aqua. 263, 238-248. https://doi.org/10.1016/j. aquaculture.2006.10.028

Enzenros L, Enzenros R. 2001. Untersuchungn uber das Vorkommen mariner Mollusken in Tunesichen Gewassern. in Zmouri-Langar N, Chouba L, Ajjahi Chebil L, Mrabet R, El Abed A. 2011. (Ed.) Les coquillages Bivalves des côtes Tunisiennes, Bull. Inst. Natn. Scien. Tech. Mer de Salmmbô, Tunisienne d'Imprimerie Papetrie (TIP), Tunis, pp. 128.

FAO. 1987. Fiches FAO d'identification des espèces pour les besoins de la pêche en Méditerranée et Mer Noire, Zone de pêche. 33I, pp. 760.

Fenton WS, Hibbeln J, Knable M. 2000. Essential fatty acids, lipid membrane abnormalities, and the diagnosis and treatment of schizophrenia. Biol. Psychiat. 47, 8-21.

Fernández-Reiriz MJ, Labarta U, Babarro JMF, 1996. Comparative allometries in growth and chemical composition of mussel (Mytilus galloprovincialis, Lmk.) cultured in two zones in the Ríasada (Galicia, NW Spain). J. Shellfish. Res. 15, 349-353.

Folch J, Lees M, Sloane-Stanle GA. 1957. A simple method for the isolation and purification of total lipids from animal tissues. J. Biol. Chem. 226, 497-509.

Galap C, Netchitaîlo P, Leboulenger F, Grillot P. 1999. Variations of fatty acid contents in selected tissues of the female dog cockle (Glycymeris glycymeris L., Mollusca, Bivalvia) during the annual cycle. Comp. Biochem. Physiol 122 (A), 241-254. https://doi.org/10.1016/S1095-6433(99)00006-9

Garrido JL, Medina I. 2002. Identification of minor fatty acids in mussels (Mytilus galloprovincialis) by GC-MS of their 2-alkenyl-4, 4-dimethyloxazoline derivatives. Anal. Chim. Acta 465, 409-16. https://doi.org/10.1016/S0003-2670(02)00207-6

Ghribi F, Boussoufa D, Aouini F, Bejaoui S, Chetoui I, Rabeh I, El Cafsi M. 2018. Seasonal variation of biochemical composition of Noah's ark shells (Arca noae L. 1758) in a Tunisian coastal lagoon in relation to its reproductive cycle and environmental conditions. Aquat. Living Resour. 31, 1-14. https://doi.org/10.1051/alr/2018002

Gil A. 2002. Polyunsaturated fatty acids and inflammatory diseases. Biomed. Pharmacother. 56, 388-396. https://doi.org/ 10.1016/S0753-3322(02)00256-1

Hanus LO, Levitsky DO, Shkrob I, Dembitsky VM. 2009. Plasmalogens, fatty acids and alkyl glyceryl ethers of marine and freshwater clams and mussels. Food. Chem. 116, 491498. https://doi.org/10.1016/j.foodchem.2009.03.004

Harris WS, Von Schacky C. 2004. The Omega-3 Index: A new risk factor for death from coronary heart disease. Prev. Med. 39, 212-220. https://doi.org/10.1016/j.ypmed.2004.02.030

Saito H. 2007. Identification of novel $n-4$ series polyunsaturated fatty acids in a deep-sea clam Calyptogena phaseoliformis. J. Chromatogr. A. 1163, 247-259. https://doi.org/10.1016/j. chroma.2007.06.016

HMSO. 2001. Nutritional aspects of cardiovascular disease: Report on health and social subjects, London, Department of Health

Holland DL. 1978. Lipid reserves and energy metabolism in the larvae of benthic marine invertebrates. in Malins DC, Sargent JR. (Ed.) Biochemical and biophysical perspectives in marine biology, London Academic Press, London, pp. $85-123$.

Kawashima H, Ohnishi M. 2003. Fatty acid Composition of various Tissue Lipids in the Marine Bivalves, Megangulus zyonoensis and Megangulus zyonoensis from coastal Waters of Hokkaido, Northern Japan. J. Oleo. Sci. 52, 309-3015. https://doi.org/10.5650/jos.52.309

Keller U, Battaglia RE, Beer M, Darioli R, Meyer K, Renggli A, Römer-Lüthi C, Stoffel-Kurt N. 2012. Sixième rapport sur la nutrition en Suisse. Berne, Office fédéral de la santé publique, Suisse, 20. pp.

Kraffe E, Soudant P, Marty Y, Kervarec N. 2005. Docosahexaenoic Acid-and Eicospentaenoi Acid- Enriched Cardiolipin in the Manila clam Rudipaes phlippinarum. Lipids 40, 619-625. https://doi.org/10.1007/s11745-005-1423-Z

Le Pennec G, Le Pennec M, Beninger P.G. 2001. Seasonal digestive gland dynamics of the scallop Pecten maximus in the bay of Brest (France). J. Mar. Biol. Assoc. UK 81, 663-671. https://doi.org/10.1017/S0025315401004349

Li Q, Lin Y, Qiaozhen K, Lingfeng K. 2011. Gametogenic cycle and biochemical composition of the clam Mactra chinensis (Mollusca: Bivalvia): Implications for aquaculture and wild stock management. Mar. Biol. 
Res. 7, 407-415. https://doi.org/10.1080/17451000.2010.5 15686

Mnari A. 2000. Etude Comparative de la composition en acides gras chez la Daurade (Sparus aurata) sauvage et élevage. D.E.A., ISBM, pp.92.

Napolitano GE, MacDonald BA, Thompson RJ, Ackman RG.1992. Lipid composition of eggs and adductor muscle in giant scallops (Placopecten magellanicus) from different habitats. Mar. Biol. 113, 71-76. https://doi.org/10.1007/BF00367640

Nevejan N, Saeza I, Gajardoa G, Sorgeloos P. 2003. Energy vs. essential fatty acids: what do scallop larvae (Argopecten purpuratus) need most? Comp. Biochem. Physiol. 134(B), 599-613. https://doi.org/10.1016/S1096-4959(03)00020-4

Paradis M, Ackman RG. 1975. Occurrence and chemical structure of non-methylene-interrupted dienoic fatty acids in American oyster Crassostrea virginica. Lipids 10, 12-16. https://doi.org/10.1007/BF02532187

Pazos AJ, Sánchez JL, Roman G, Pérez-Parallé M, Abad M. 2003. Seasonal changes in lipid classes and fatty acids composition in the digestive gland of Pecten maximus. Comp. Biochem. Physiol. 134(B), 367-380.

Pernet F, Tremblay R, Comeau L, Guderley H. 2007. Temperature adaptation in two bivalve species from different thermal habitats: energetics and remodelling of membrane lipids. J. Exp. Biol. 210, 2999-3014. https://doi.org/10.1242/jeb.006007

Prato E, Danieli A, Maffia M, Biandolino F. 2010. Lipid and Fatty Acid Compositions of Mytilus galloprovincialis Cultured in the Mar Grande of Taranto (Southern Italy): Feeding Strategies and Trophic Relationships. Zoological Studies 49(2), 211-219.

Qiaozhen K, Qi Li. 2013. Annual dynamics of glycogen, lipids and proteins during the reproductive cycle of the surf clam
Mactra veneriformis from the north coast of Shandong Peninsular, China. Inver. Reprod. Dev. 57, 49-60. https:// doi.org/10.1080/07924259.2012.664174

Seurat LG. 1924. Observations sur les limites, les faciès et les associations de l'étage intercôtidal de la petite syrte (Golfe de Gabès). Bull. Sta. Océanogr. Salammbô, 3, 72. pp.

Shanmugam A, Palpandi C, Sambasivam S. 2007. Some valuable fatty acids exposed from wedge clam Donax cuneatus (Linnaeus), AFJR 1(2), 014-018.

Sprecher H. 2000. Metabolism of highly unsaturated $n-3$ and $n-6$ fatty acids. Biochem. Biophys. Acta 1486, 219-231. https:// doi.org/10.1016/S1388-1981(00)00077-9

Telahigue K, Chetoui I, Rebeh I, Romdhane MS, El Cafsi M. 2010. Comparative fatty acid profiles in edible parts of wild Scallops from the Tunisian coast. Food. Chemistry 122, 744-746. https://doi.org/10.1016/j.foodchem.2010.03.047

Teshima SI, Kanazawa A, Shimamoto R. 1988. Anatomical distribution of sterols and fatty acid in the bivalve Mactra chinensis. Nippon Suisan Gakk. 54, 293-297. https://doi. org/10.2331/suisan. 54.293

World Health Organization. 2008. Interim summary of conclusion and dietary recommendations on total fat \& fatty acids. From the joint FAO/WHO expert consultation on fats and fatty acids in human nutrition, 10-14 November 2008, Geneva. in Keller U, Battaglia R. E, Beer M., Darioli R, Meyer K, Renggli A, Römer-Lüthi C, Stoffel-Kurt N. 2012 (ed.) Sixième rapport sur la nutrition en Suisse, Berne, Office fédéral de la santé publique, Suisse, pp. 20.

Zhukova NV. 1991. The pathway of the biosynthesis of nonmethylene-interrupted dienoic fatty acids in mollusks. Comp. Biochem. Physiol. 100 (B), 801-804. https://doi.org/ 10.1016/0305-0491(91)90293-M 